\title{
Dampak Kebijakan dan Keberhasilan Tax Amnesty Bagi Perekonomian Indonesia
}

\author{
Yuwita Ariessa Pravasanti \\ STIE-AAS \\ yuwita.ariessa.pravasanti@gmail.com
}

\begin{abstract}
The main source of state revenue is derived from tax, even though the tax revenue is still not maximized. This condistion is caused by the realization of tax revenues has not met the targets which are set by the government. Ther are various ways that have been done by the government in raising the state revenues, one of them is tax amnesty policyin 2016 and 2017. Tis research aims to know the impact of the policy and the success of the tax amnesty for the Indonesian economy. This research uses qualitative method with descriptive explorative approach. The result of this research shows that tax amnesty policies in Indonesia are considered successful and have an impact on the country's economy.
\end{abstract}

Keywords: tax, tax amnesty

\begin{abstract}
ABSTRAK
Sumber utama dari penerimaan negara berasal dari pajak, meskipun begitu penerimaan pajak masih dinilai belum maksimal. Ini dikarenakan realisasi penerimaan pajak belum memenuhi target yang ditentukan oleh pemerintah. Berbagai cara telah dilakukan oleh pemerintah dalam menaikkan penerimaan negara, salah satunya adalah kebijakan tax amnesty pada tahun 2016 dan 2017. Penelitian ini bertujuan untuk mengetahui dampak kebijakan dan keberhasilan tax amnesty bagi perekonomian Indonesia. Penelitian ini menggunakan metode kualitatif dengan pendekatan eksploratif deskriptif. Hasil dari penelitian ini menunjukkan bahwa kebijakan tax amnesty di Indonesia dinilai berhasil dan berdampak terhadap perekonomian negara.
\end{abstract}

Kata Kunci: Pajak, Tax Amnesty

\section{LATAR BELAKANG}

Indonesia adalah salah satu Negara berkembang yang tingkat perekonomiannya rendah. Pendapatan utama negara Indonesia berasal dari Pajak. Menurut Mardiasmo (2016), pajak dapat diartikan sebagai pungutan yang dilakukan oleh negara kepada warga negaranya berdasarkan undang-undang, dimana atas pungutan tersebut negara tidak memberikan kontraprestasi secara langsung kepada warga negaranya. Pajak sebagai penerimaan negara harus dinilai positif, karena melalui pajak kemandirian suatu negara dalam membiayai pembangunan dan pemerintahannya dapat tercapai. Suluruh biaya yang dibutuhkan untuk pembangunan dan pengembangan negara berasal dari masyarakat sendiri, bukan dari bantuan negara lain. Keadaan yangseperti ini akan berdampak pada kemandirian negara yang lebih kuat sehingga negara tidak bergantung pada negara lain dalam pembiayaan pembangunan dalam negaranya. Oleh karena itu, pajak yang memiliki peran strategis ini seharusnya mendapatkan perhatian penting dari masyarakat dan pemerintah. Purnamawati 
(2014) menyatakan bahwa sistem pajak yang ideal bagi suatu negara harus mempunyai prinsip manfaat (benefit principle) yaitu diharapkan manfaat lebih tinggi dibandingkan pajak yang dibayar oleh Wajib Pajak serta pajak harus mempunyai prinsip keadilan (equity principle).

Tabel 1. Penerimaan Negara dalam APBN 2017

\begin{tabular}{|c|c|c|c|}
\hline No. & Uraian & Jumlah (Dalam Triliun) & Presentase (\%) \\
\hline 1 & Pajak & $1.498,90$ & 85,6 \\
\hline 2 & Pendapatan Negara Bukan Pajak & 250,00 & 14,3 \\
\hline 3 & Hibah & 1,40 & 0,1 \\
\hline & Total & $1.750,3$ & 100 \\
\hline
\end{tabular}

Sumber: Kementrian Keuangan Republik Indonesia, 2018

Penerimaan pajak merupakan tonggak dari penerimaan negara. Pada tahun 2017, pajak telah menyumbang $85,6 \%$ dari seluruh penerimaan negara. Walaupun begitu, penerimaan pajak masih dinilai belum maksimal. Realisasi penerimaan pajak masih belum memenuhi target yang sudah ditetapkan oleh pemerintah. Berbagai upaya telah dilakukan oleh pemerintah maupun lembaga-lembaga yang berhubungan dengan perpajakan.Salah satu kebijakan yang telah dikeluarkan oleh pemerintah dalam menaikkan penerimaan adalahdengan adanya kebijakan pengampunan pajak (tax amnesty). Tax amnesty merupakan kebijakan pemerintah yang digunakan untuk menghimpun penerimaan negara dalam waktu yang cepat. Tax amnesty dilakukan dengan berbagai penyebab, yaitu: banyaknya aktivitas underground economy atau penggelapan pajak (tax evasion), pelarian modal ke luar negeri (capital flight), rekayasa transaksi keuangan, serta politik penganggaran untuk menghadapi kontraksi anggaran negara yang sedang terjadi.

Mattielo (2005) menyatakan bahwa kebijakan tax amnesty mempunyai manfaat jangka panjang dan jangka pendek. Dalam jangka pendek, tax amnesty dapat meningkatkan penerimaan negara serta kepatuhan wajib pajak, dan dalam waktu jangka panjangnya, wajib pajak tidak dapat menghindari kewajiban perpajakannya dikarenakan data harta wajib pajak sudah dilaporkan kepada pemerintah di tahun sebelumnya.

Tax amnesty sendiri apabila dilihat dari undang-undang perpajakan juga masih menjadi perdebatan, dikarenakan adanya penghapusan sanksi dan denda yang seharusnya dikenakan kepada wajib pajak. Sesuai dengan Undang Undang no 28 tahun 2007 tentang ketentuan umum dan tata cara perpajakan, wajib pajak seharusnya membayar hutang pajak berserta sanksi administrasi dan denda keterlambatan pembayaran pajak. Namun pada kebijakan tax amnesty, justru wajib pajak diampuni seluruhnya hanya dengan uang tebusan yang nominalnya jauh dibawah utang pajak yang seharusnya dibayar oleh wajib pajak. Namun tak bisa dipungkiri, bahwasannya kebijakan tax amnesty ini merupakan salah satu cara dalam menaikkan penerimaan pajak dalam waktu yang cepat. 
Tax amnesty merupakan suatu kebijakan pemerintah di bidang perpajakan dengan melakukan penghapusan pajak yang seharusnya terutang dengan membayar tebusan dalam jumlah tertentu dengan tujuan memberikan kesempatan kepada wajib pajak yang tidak patuh terhadap pajak menjadi patuh, selain itu juga dapat menambah penerimaan suatu negara. Kebijakan Tax Amnesty pertama kali berlaku di Indonesia pada tahun 1964. Di Era pemerintahan Soekarno, kebijakan ini dikeluarkan untuk mengembalikan dana revolusi pada saat itu. Tax Amnesty tidak berjalan dengan baik, sehingga dilakukan kembali pada tahun 1984. Pada tahun 1984 ini, kebijakan Tax Amnesty selain untuk memperoleh penerimaan pajak, juga mengubah sistem perpajakan yang berlaku, yaitu dari Official Assesment System (perhitungan besarnya jumlah pajak ditentukan oleh pemerintah) menjadi Self Assesment System (perhitungan besar pajak dilakukan oleh wajib pajak sendiri).Namun tax amnesty yang dilakukan pada tahun 1984, masih belum sempurna dikarenakan adanya dugaan KKN, yaitu Pada tahun 2016, Presiden Joko Widodo mengesahkan UU Tax Amnesty No. 11 tahun 2016 tentang pengampunan pajak.

Kebijakan tax amnesty tahun 2016 dilakukan kembali dengan beberapa alasan, yaitu;1) banyaknya harta milik wajib pajak baik di dalam maupun luar negeri yang belum dilaporkan dalam surat pemberitahuan tahunan pajak penghasilan; 2) meningkatkan penerimaan negara dan pertumbuhan perekonomian serta kepatuhan dan kesadaran wajib pajak; 3) kasus panama papers tentang praktik tersembunyinya harta kekayaan serta penghindaran pembayaran pajak diluar kelaziman.

Implementasi perpajakan dalam pelaksanaannya di negara Indonesia masih mempunyai permasalahan tersendiri. Pertama, kepatuhan wajib pajak di Indonesia masih rendah. Kedua, kekuasaan Direktorat Jenderal Pajak (DJP) masih besar (mencakup fungsi eksekutif, legislatif, dan yudikatif) sehingga menimbulkan terjadinya ketidakadilan dalam melayani hak-hak wajib pajak yang berdampak pada turunnya tingkat kepatuhan wajib pajak. Ketiga, masih rendahnya kepercayaan wajib pajak kepada aparat pajak, serta berbagai aturan perpajakan yang dinilai rumit.

Implementasi kebijakan yang berkaitan dengan pengampunan pajak (tax amnesty) merupakan salah satu agenda reformasi di bidang perpajakan di Indonesia yang sudah dilakukan tahun 2016. Walaupun Tax amnesty ini sudah dilakukan beberapa kali, namun keberhasilannya belum dirasakan ditahun-tahun sebelumnya. Berkaitan dengan hal tersebut, penulis mencoba untuk meneliti dampak kebijakan tax amnesty bagi perekonomian indonesia.Penelitian ini bertujuan untuk mengetahui dampak kebijakan tax amnesty terhadap perekonomian Indonesia. Demikian juga akan dapat diketahui keberhasilan kebijakan tax amnestyyang sudah dilakukan tahun 2016-2017. Hubungan antara tax amnesty dengan penerimaan pajak mengacu pada penelitian sebelumnya oleh 
Ngadiman dan Huslin (2015), yang menunjukkan bahwa tax amnesty berpengaruh positif signifikan terhadap kepatuhan wajib pajak. Jika penerapan tax amnesty semakin tinggi, maka kepatuhan wajib pajak juga semakin tinggi.

\section{TINJAUAN PUSTAKA \\ Pengertian Pajak}

Beberapa ahli memberikan batasan tentang pajak, diantaranya pengertian pajak yang dikemukakan oleh Brotodihardjo R. Santoso (1998) menyebutkan bahwa:

"Pajak adalah iuran kepada negara (yang dapat dipaksakan) yang terutang oleh yang wajib membayarnya menurut peraturan-peraturan, dengan tidak mendapat prestasi kembali yang langsung ditunjuk, dan yang gunanya adalah untuk membiayai pengeluaran-pengeluaran umum berhubung dengan tugas negara yang menyelenggarakan pemerintahan."

Pengertian lain dari pajak menurut UU No. 28 tahun 2007:

"Pajak adalah kontribusi wajib kepada Negara yang terutang oleh orang pribadi atau badan yang bersifat memaksa berdasarkan undang-undang dengan tidak mendapatkan imbalan secara langsung dan digunakan sebesar-besarnya untuk keperluan negara bagi kemakmuran rakyat."

Sistem pemungutan pajak yang diterapkan di Negara Indonesia adalah sistem self-assessment. Sistem pemungutan pajak ini menuntut seorang wajib pajak untuk berperan aktif dan sadar dalam melakukan kewajiban perpajakannya. Anggraeni (dalam Herryanto dan Toly, 2013) menyimpulkan bahwa kriteria wajib pajak yang memiliki kesadaran kewajiban perpajakannya dalam sistem selfassessment, adalah:

1. Mendapatkan NPWP, wajib pajak secara aktif mendaftarkan diri secara aktif dan mandiri ke KPP setempat sesuai dengan domisili dalam KTP.

2. Wajib pajak mengambil sendiri formulir SPT Masa di KPP setempat.

3. Wajib pajak menghitung dan menetapkan sendiri jumlah pajak penghasilan yang terutang melalui pengisian SPT tanpa bantuan fiskus.

4. Wajib pajak menyetor dan melaporkan sendiri formulir SPT secara aktif dan mandiri dan tepat waktu, tanpa harus ditagih oleh fiskus.

\section{Tax Amnesty}

Amnesty berasal dari bahasa yunani "amnestia" yang berarti lupa akan suatu hal atau kejadian yang berlalu. Tax amnesty (pengampunan pajak) adalah suatu penghapusan pajak yang seharusnya terutang, tidak dikenai sanksi administrasi perpajakan dan sanksi pidana dibidang perpajakan, dengan cara 
mengungkap Harta dan membayar Uang Tebusan (UU pengampunan pajak 2016). Pengertian lain dari Tax Amnesty yaitu salah satu upaya yang dilakukan oleh otoritas pajak suatu negra untuk memberikan kesempatan kepada Wajib Pajak yang selama ini tidak patuh untuk melaporkan penghasilannya dan membayar pajak secara sukarela melalui pemberin insentif (Mukarromah dkk, 2016). Terkait dengan kebijakan pemerintah berupa pemberlakuan Tax Amnesty, pemerintah memberikan kesempatan terhadap Wajib Pajak untuk memperbaiki atas kekurangan kewajiban perpajakan dimasa lalu dengan seluruh pembayaran pokok dan dibeaskan dari seluruh denda, bunga, dan sanksi pidana fiskal (tax crime). UU No. 11 tahun 2016 menyatakan bahwa tax amnesty adalah penghapusan pajak yang seharusnya terutang, tidak dikenai sanksi administrasi perpajakan dan sanksi pidana di bidang perpajakan, dengan cara mengungkap harta dan membayar uang tebusan sebagaimana diatur dalam undang-undang ini. Terdapat beberapa pertimbangan sebelum melakukan pengampunan pajak ini, yaitu:

1. Underground economy. Kegiatan ekonomi yang sengaja disembunyikan untuk menghindari pajak.

2. Capital flight. Pelarian modal ke luar negeri dengan cara ilegal.

3. Terdapat rekayasa keuangan yang berakibat hilangnya potensi penerimaan pajak.

4. Politik mpenganggaran untuk menghadapi kontraksi anggarapn negara yang terjadi.

Beberapa jenis tax amnesty yang ada di dunia, yaitu:

1. Tax amnesty yang tetap mewajibkan membayar pokok pajak, termasuk bunga dan denda, dan hanya mengampuni sanksi pidana perpajakan.

2. Tax amnesty yang mewajibkan membayar pokok pajak beserta bunganya, namun melakukan pengampunan terhadap sanksi, baik sanksi denda maupun sanksi perpajakannya.

3. Tax amnesty yang mewajibkan membayar pokok pajaknya saja. Untuk bunga, sanksi denda, maupun sanksi perpajakan ditiadakan/ diampuni.

4. Tax amnesty yang mengampuni semua pokok pajak masa lalu, bunga, sanksi denda, maupun sanksi perpajakannya.

Tujuan dari tax amnesty adalah untuk meningkatkan penerimaan Negara dan pertumbuhan perekonomian, serta meningkatkan kesadaran dan kepatuhan masyarakat dalam melaksanakan kewajiban perpajakan. Tax amnesty adalah salah satu cara yang dilakukan oleh pemerintah untuk menarik modal yang disimpan di luar negeri oleh Wajib Pajak baik Wajib Pajak Orang Pribadi maupun Wajib Pajak Badan ke Indonesia. Wajib Pajak Orang Pribadi dan Wajib Pajak Badan yang melaporkan hartanya dan membawa pulang ke Indonesia tidak 
akan dikenai sanksi tetapi hanya wajib membayar uang tebusan yang perhitungannya sudah di tentukan sebelumnya oleh pemerintah.

Tabel 2. Tarif dan Periode Penetapan Tax Amnesty

\begin{tabular}{lcc}
\hline \multirow{2}{*}{ Periode } & \multicolumn{2}{c}{ Besaran Uang Tebusan } \\
\cline { 2 - 3 } & $\begin{array}{c}\text { Harta di Indonesia/ harta } \\
\text { dari LN di pindah ke } \\
\text { Indonesia }\end{array}$ & $\begin{array}{c}\text { Pengungkapan harta dan } \\
\text { hartanya tetap di LN }\end{array}$ \\
\hline 01 Juli s/d 30 September 2016 & $2 \%$ & $4 \%$ \\
01 Oktober s/d 31 Desember 2016 & $3 \%$ & $6 \%$ \\
01 Januari s/d 31 Maret 2017 & $5 \%$ & $10 \%$ \\
\hline Sumber: UU pengampunan pajak 2016 & &
\end{tabular}

\section{METODE PENELITIAN}

Penelitian ini menggunakan metode kualitatif dengan pendekatan eksploratif deskriptif. Kotler dan Keller (2006) menyatakan bahwa pendekatan eksploratif adalah metode penelitian yang bertujuan menghimpun informasi awal yang akan membantu upaya menetapkan masalah dan merumuskan hipotesis. Pengertian pendekatan deskriptif adalah metode penelitian yang bertujuan memaparkan (mendeskripsikan) sesuatu hal. Sehingga dapat disimpulkan bahwa pendekatan ini bertujuan untuk mendalami mengenai kebijakan tax amnesty di Indonesia. Bahan penelitian dan informasi berasal dari data sekunder yang berasal dari penggalian informasi dari berbagai sumber, bahan seminar, media masa, media elektronik, dan lain-lain serta didukung pula dengan kajian pustaka.

\section{HASIL DISKUSI DAN KESIMPULAN}

Menurut Lofchie (1989) dalam Wardiyanto (2009) implementasi kebijakan seringkali gagal diterapkan (unsuccesful implementation) dikarenakan adanya keterbatasan administrasi, ekonomi dan politik. Masalah administrasi muncul dikarenakan adanya kekacauan dan ketidakmampuan/ kurangnya tenaga ahli dan dukungan politik bagi pejabat sipil dan kaum birokrat di Dunia. Pada masalah yang bersifat ekonomi muncul karena kurangnya dana untuk membiayai sejumlah proyek dan program yang ingin diadakan oleh pemerintah, serta hambatan-hambatan politik atas pelaksanaan kebijakan, selain itu juga adanya ketidak disiplinan sosial dalam hukum, ketidakpercayaan kepada institusi negara, ketidaktaatan pegawai pemerintah kepada peraturan dan petunjuk yang disampaikan kepada mereka, dan sering terjadi persekongkolan antara pegawai pemerintah dengan kelompok yang kuat.

Sawyer (2016) menyatakan beberapa tipe/ model pengampunan pajak (Tax Amnesty), yaitu:

1. Filling amnesty. Pengampunan pajak yang diberikan dengan cara menghapuskan sanksi bagi Wajib Pajak yang terdaftar yang tidak melaporkan 
SPT, pengampunan diberikan apabilawajib pajak mau mulai untuk mengisi SPT.

2. Record-keeping amnesty. Negara Memberikan penghapusan sanksi dalam halwajib pajak mengalami kegagalan dalam memelihara dokumen perpajakan di masa lalu, pengampunan pajak diberikan apabila Wajib Pajak untuk selanjutnya dapat memelihara dokumen perpajakannya.

3. Revision amnesty. Merupakan suatu kesempatan yang diberikan kepada wajib pajak untuk memperbaiki SPT di masa lalu tanpa dikenakan sanksi atau diberikan pengurangan sanksi. Pengampunan ini memungkinkan untuk Wajib Pajak memperbaiki SPT-nya (yang menyebabkan adanya pajak yang masih harus dibayar wajib pajak) dan membayar pajak yang tidak (missing) atau belum dibayar (outstanding), Namundengan demikian Wajib Pajak tidak akan secara otomatis kebal terhadap adanya tindakan pemeriksaan dan penyidikan dari fiskus.

4. Investigation amnesty.Pengampunan yang menjanjikan kepada wajib pajak bahwa fiskus tidak akan menyelidiki sumber penghasilan yang dilaporkan pada tahun-tahun tertentu dan terdapat sejumlah uang pengampunan (amnesty fee) yang harus dibayar (tebusan). Pengampunan jenis ini juga menjanjikan untuk tidak akan dilakukannya tindakan penyidikan terhadap sumber penghasilan atau jumlah dari penghasilan yang sebenarnya. Pengampunan ini lebih sering dikenal dengan pengampunan yang erat dengan tindak pencucian (laundering amnesty).

5. Prosecution amnesty.Pengampunan yang memberikan penghapusan tindak pidana bagi Wajib Pajak yang melanggar undang-undang perpajakan, sanksi dihapuskan dengan membayarkan sejumlah kompensasi.

Implementasi pengampunan pajak di Indonesia memiliki peluang untuk berhasil dilaksanakan dengan jenis investigation amnesty. Tax amnesty merupakan harapan yang besar bagi pemerintah Indonesia untuk dapat memasukan dana dari luar negeri ke Indonesia. Hal ini di yakini oleh pemerintah karena Wajib Pajak tidak akan merasa ketakutan untuk memasukan hartanya di Indonesia sebab denda telah dihapuskan, setelah melakukan tax amnesty semua catatan perpajakan yang di miliki oleh Wajib Pajak menjadi bersih. Efek negatif dari tax amnesty adalah pada kepatuhan sukarela Wajib Pajak. Hasil dari peraturan tersebut adalah Wajib Pajak memiliki harapan yang tinggi dari tax amnesty dan akan menjadi kebiasaan (Nar, 2015).

Berdasarkan Tabel 1, dapat diketahui bahwasannya penerimaan dari tax amnesty sendiri sebesar 109,05T pada tahun 2016, dapat disimpulkan bahwasannya tax amnesty menyumbang $13 \%$ dari seluruh penerimaan pajak penghasilan yang diperoleh. Pada tahun 2017 tax amnesty hanya berlaku 1 periode saja yaitu pada tanggal 1 januari 2017 sampai dengan 31 maret 2017. Dalam 
waktu 3 bulan, penerimaan tax amnestysebesar 25,5T atau menyumbang 3,25\% dari seluruh penerimaan pajak penghasilan pada tahun 2017.

Tabel 3. Penerimaan Pajak (dalam Triliun Rupiah)

\begin{tabular}{|c|c|c|c|c|c|}
\hline Sumber Penerimaan & 2013 & 2014 & 2015 & 2016 & 2017 \\
\hline Penerimaan Perpajakan & $1.077,31$ & $1.146,87$ & $1.240,42$ & $1.539,25$ & $1.495,89$ \\
\hline Pajak Dalam Negeri & $1.029,85$ & $1.103,22$ & $1.205,48$ & $1.503,30$ & $1.461,82$ \\
\hline - Pajak Penghasilan & 506,44 & 546,18 & 602,31 & 855,84 & 784,73 \\
\hline - PPN & 384,71 & 409,18 & 423,71 & 474,23 & 493,89 \\
\hline - $\mathrm{PBB}$ & 25,30 & 23,48 & 29,25 & 17,71 & 17,30 \\
\hline - ВРНТВ & 0 & 0 & 0 & 0 & 0 \\
\hline - Cukai & 108,45 & 118,09 & 144,64 & 148,09 & 157,16 \\
\hline - Pajak Lainnya & 4,94 & 6,29 & 5,57 & 7,41 & 8,75 \\
\hline Pajak Perdagangan Internasional & 47,46 & 43,65 & 34,94 & 35,87 & 34,07 \\
\hline - Bea Masuk & 31,62 & 32,32 & 31,21 & 33,37 & 33,74 \\
\hline - Pajak Ekspor & 15,84 & 11,32 & 3,73 & 2,50 & 0,34 \\
\hline
\end{tabular}

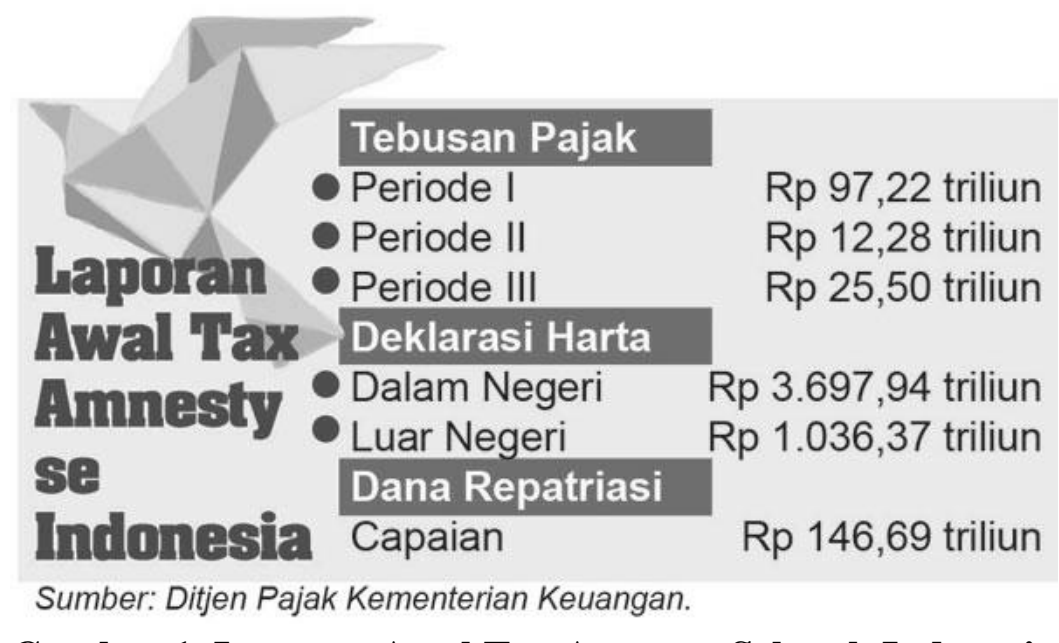

Gambar 1. Laporan Awal Tax Amnesty Seluruh Indonesia

\section{Tolak ukur keberhasilan Tax Amnesty:}

1. Mampu menaikkan penerimaan negara.

2. Mampu menarik dana dari repatriasi modal.

3. Mampu menggerakkan sektor ekonomi dan memperkuat basis data untuk menguji wajib pajak di masa yang akan datang.

4. Meningkatkan kepatuhan wajib pajak.

\section{Dampak Kebijakan tax amnesty dinilai berhasil, dikarenakan:}

1. Mampu menaikkan pertumbuhan ekonomi mencapai 5,3\% ditahun 2016 dan 5,1\% ditahun 2017.

2. Mendorong dana masuk ke negara Indonesia yang berakibat meningkatkan cadangan devisa serta memperkuat nilai tukar rupiah. Data BI mencatat 
september 2016 sebesar US\$ 115,7 milyar, lebih tinggi dibandingkan dengan posisi agustus sebesar US\$113,5 milyar.

3. Berdampak positif terhadap BEI. BEI menyatakan bahwa terdapat belasan perusahaan yang melakukan go public. Banyaknya dana yang masuk dari tax amnesty, mendorong BEI untuk mengajak para pelaku pasar memanfaatkan peluang dan mendorong BUMN dan BUMD untuk go public.

4. Berdampak positif terhadap bisnis manufaktur, properti dan investasi.

5. BPS mencatat september 2016 terjadi inflasi $0,22 \%$ sehingga inflasi januari hingga september mencapai $1,97 \%$ dan tingkat inflasi dari tahun ke tahun $3,07 \%$.

\section{REFERENSI}

Agung, M. 2007. Perpajakan Indonesia, Teori dan Aplikasi. Dinamika Ilmu.

Alm, J., Jorge, M., Vazquez, and Sally, W. 2009. Do Tax Amnesty Work? The Revenue Effect of Tax Amnesties During The Transition in The Russian Federation. Economic Analysis \& Policy, 32: 15-20.

Brotodihardjo R. Santoso. 1998. Pengantar Hukum Pajak. Bandung: Refika Aditama.

Fisher R. C, John H.G, and James C, Y. 1989. Participation In Tax Amnesties: The Individual Income Tax. National Tax Journal, 42(1) : 15-27.

Herryanto, M., \& Toly, A. A. 2013. Pengaruh kesadaran wajib pajak, kegiatan sosialisasi perpajakan, dan pemeriksaan pajak terhadap penerimaan pajak penghasilan di KPP Pratama Surabaya Sawahan. Tax and Accounting Review, 1(1): 125-133.

https://dbs.com/indonesia-bh/blog/live-smart/pengaruh-postif-tax-amnestyterhadap-pertumbuhan-ekonomi-indonesia.pageDBSindonesia. "Pengaruh Positif Tax Amnesty Terhadap Pertumbuhan Ekonomi Indonesia". Diakses pada tanggal 17 desember 2017 pukul 18.37 WIB.

https://informasicoins.wordpress.com/2016/10/22/pengaruh-tax-amnestyterhadap-perekonomian-indonesia. "Pengaruh tax amnesty terhadap perekonomian Indonesia”. Diakses pada tanggal 17 Desember 2017.

https://kemenkeu.go.id

https://www.kompasiana.com/tax-amnesty-dan-pengaruhnya-terhadapperekonomian-indonesia."Tax amnesty dan pengaruhnya terhadap perekonomian Indonesia”. Diakses pada tanggal 17 desember 2017.

https://lembagapajak.com

https://pengampunanpajak.com 
https://thinktank.matagaruda.org/read/78/peran-tax-amnesty-dalam-pertumbuhanekonomi-indonesia. "Wibowo, Ari. 2017. Peran Tax Amnesty Dalam Pertumbuhan Ekonomi Indonesia". Diakses pada tanggal 17 Desember 2017.

http://vibizmanagement.com/journal.php?id=425\&sub=journal\&awal=10\&page=t ax

James Alm, Jorge Martinez-Vazquez, and Sally Wallace. 2009. Do Tax Amnesties Work? The Revenue Effects of Tax Amnesties During the Transition in the Russian Federation. Economic Analysis \& Policy, 39(12): 14-29.

Jamil, Nur Asyiah. 2017. Efektivitas Penerapan Tax Amnesty di Indonesia. Journal Of Multidisciplinary Studies Academica. 1(1): 33-41.

Kotler, Philip dan Keller, L. K. 2006. Metodologi Penelitian: Aplikasi Dalam Pemasaran, Jakarta: Indeks.

Kurnia, S. R. 2010. Perpajakan Indonesia (Konsep Dan Aspek Formal). Yogyakarta : Graha Rahayu.

Leonard, H.B dan Richard J.Z. 2015. Amnesty, Inforcemen, and Tax Policy. John F. Kennedy School of Government, Harvard University, and NBER.

Madhusudhan, Ranjana. 2012. Tax Amnesty In The American States: Comments. Revenue and Analysis, Office of Chief Economist New Jersey Department of Treasury. National Tax Association Proceedings.

Mardiasmo. 2016. Perpajakan Indonesia. Yogyakarta: Penerbit Andi.

Mattielo,G. 2005. Multiple Tax Amnesties and Tax Compliance (Forgiving Seventy Times Seven). Universita Ca'Foscari, Venezia Working Paper.

Mukarromah, Awwaliyatul, dkk. 2016. Pentingnya Peran Tax Amnesty di 2016. Insideheadline, Edisi 37.

Nar, Mehmet. 2015. The Effects of Behavioral Economics on Tax Amnesty. International Journal of Economics and Financial Issues, 5(2): 580589.

Ngadiman dan Daniel Huslin. 2015. Pengaruh Sunset Policy, Tax Amnesty, dan Sanksi Pajak Terhadap Kepatuhan Wajib Pajak. Jurnal Akuntansi, 19(2): 225-241.

Nordiansyah, Eko. 2017. Dampak pengampunan pajak bagi pertumbuhan ekonomi dan rupiah. (online). Metrotvnews.com.

Pacolo, Panico. 2010. An Appraisal Of Trusts Under The Italian Tax Amnesty. Trusts \& Trustees, 16(4): 247-249. 
Purnamawati, I Gusti Ayu. 2014. Pelaksanaan Peraturan Daerah Nomor 7 Tahun 2011 Dalam Menunjang Pendapatan Asli Daerah dari Sektor Retribusi Parkir Kendaraan Roda Dua. Pandecta Journal, 9(1): 142153.

Puspareni K. D, dkk. 2017. Pengaruh Tax Amnesty, Pertumbuhan Ekonomi, Kepatuhan Wajib Pajak, Dan Transformasi Kelembagaan Direktorat Jenderal Pajak Terhadap Penerimaan Pajak Tahun Pajak 2015 Di Kantor Pelayanan Pajak Pratama Singaraja. E-jurnal S1 Akuntansi Universitas Pendidikan Ganesha, 7(1)

Santoso, Urip \& Justina M. Setiawan. 2009. Tax Amnesty dan Pelaksanaannya di Beberapa Negara: Perspektif Bagi Pebisnis Indonesia. Sosiohumaniora, 11(2): $111-125$

Sawyer. 2016. Targeting Amnesties at Ingrained Evasion - a New Zealand Initiative Warranting Wider Consideration? Journal Taxation and Bussiness Law, Department of Accountancy Finance and Information Systems-University of Canterbury.

Sony Devano dan Siti Kurnia Rahayu. 2006. Perpajakan: Konsep, Teori dan Isu. Jakarta : Prenada Media

Undang-Undang Republik Indonesia No. 11 Tahun 2016 Tentang Tax Amnesty.

Wardiyanto, Bintoro. 2009. Kebijakan Pengampunan Pajak (Tax Amnesty) [Perspektif Kerangka Kerja Implementasi Sunset Policy mendasarkan mendasarkan UU No 28 tahun 2007]. Jurnal Masyarakat Kebudayaan dan Politik, 21(4): 328-335.

Waris Attiya, Abdul Latif Laila. 2014. The Effect of Tax Amnesty on AntiMoney Laundering in Bangladesh. Journal of Money Laundering Control, 17(2): 243-255. 